\title{
Glacier variations in the Naimona'nyi region, western Himalaya, in the last three decades
}

\author{
Qinghua YE, ${ }^{1,3 *}$ Tandong YAO, ${ }^{1,2}$ Shichang KANG, ${ }^{1,2}$ Feng $\mathrm{CHEN}^{1}{ }^{1}$ Jinghua WANG ${ }^{1}$ \\ ${ }^{1}$ Institute of Tibetan Plateau Research, Chinese Academy of Sciences, Beijing 100085, China \\ E-mail: yeqh@itpcas.ac.cn \\ ${ }^{2}$ Laboratory of Cryosphere and Environment, Cold and Arid Regions Enviornmental and Engineering Research Institute, \\ Chinese Academy of Sciences, 260 Donggang West Road, Lanzhou 730000, China \\ ${ }^{3}$ Institute of Remote Sensing Applications, Chinese Academy of Sciences, Beijing 100101, China
}

\begin{abstract}
This work quantifies glacier variations in the Naimona'nyi area of the western Himalaya by integrating glacier spatial data from ASTER and the Landsat series of satellite imagery at four different times: 1976, 1990, 1999 and 2003. Comparison of the results from individual images with those from the integrated method indicates that the integrated approach provides a better result. Glacier variations were mapped and analyzed; discrepancies between images could be detected and removed from the integrated data using remap tables in Arc/Info grid both graphically and numerically. Our results show that glaciers in the region both retreated and advanced during the last 28 years; however, retreat dominates. The variation of glaciers in the western Himalayan region is dramatic compared with other regions in high Asia. From 1976 to 2003, glacier area decreased from $84.41 \mathrm{~km}^{2}$ to $77.29 \mathrm{~km}^{2}$. Sequential images show that glacier areas shrank by $0.17,0.19$ and $0.77 \mathrm{~km}^{2} \mathrm{a}^{-1}$, on average, during the periods 1976-90, 1990-99 and 1999-2003, respectively, suggesting that glacier retreat has accelerated.
\end{abstract}

\section{INTRODUCTION}

Alpine glaciers, especially those in temperate zones, are regarded as one of the best natural indicators of climate change and they have generally receded during the 20th century (Dyurgerov and Meier, 2000). Hence there is a need for detailed global monitoring of glaciers (Oerlemans, 1994; Haeberli and others, 1999; Yao and others, 2004). Glaciers on the Tibetan Plateau play an important role in the global climate system (Zheng and Zhu, 2003). Researchers have focused on alpine glacier variations in high Asia over the last few decades and found a general reduction in glacier area in the region (e.g. Mayewski and others, 1979; Miller, 1984). According to many studies (Chen and others, 1996; Su and others, 1999; Pu and others, 2001; Wang and Liu, 2001; Jing and others, 2002; Liu and others, 2002; Lu and others, 2002), glacial retreat varies spatially across the Tibetan Plateau. Glacier recession rates are lower inland and higher at the margin of the Tibetan Plateau (Yao and others, 2004).

Due to the large number and remoteness of most alpine glaciers, remote-sensing satellite techniques, including microwave data and optical imagery, have been frequently used in global-scale surveys. Landsat imagery, including the Landsat Multispectral Scanner (MSS; four spectral bands in the visible/near-infrared (VNIR) parts of the electromagnetic spectrum with $57 \mathrm{~m}$ resolution), the Landsat Thematic Mapper (TM; seven spectral bands from the visible to the thermal-infrared part of the spectrum with $28.5 \mathrm{~m}$ spatial resolution in VNIR) and the Landsat Enhanced Thematic Mapper Plus (ETM+; eight discrete bands with $14.25 \mathrm{~m}$ spatial resolution in the panchromatic band), has been one of the primary data sources for glaciological research (Bindschadler and others, 2001) because it provides glacier information in remote areas since the beginning of the series in 1972 (Meier, 1973). Imagery from the Advanced Spaceborne Thermal Emission and Reflection Radiometer (ASTER), which employs 14 discrete bands with three bands in VNIR with $15 \mathrm{~m}$ resolution and a $15 \mathrm{~m}$ resolution NIR along-track stereo band looking backward $27.6^{\circ}$ from nadir (Kääb, 2002), is also widely used for assessment of glacier dynamics in many programs (e.g. the Global Land Ice Measurements from Space (GLIMS) project (Bishop and others, 2004)).

Naimona'nyi, the highest peak of the western Himalayan mountains, with an elevation of $7694 \mathrm{~m}$, is located in the southwestern region of the Tibetan Plateau $\left(30^{\circ} 04^{\prime}-\right.$ $\left.31^{\circ} 16^{\prime} \mathrm{N}, 81^{\circ}-81^{\circ} 47^{\prime} \mathrm{E}\right)$. Many researchers have focused on alpine glacier variations in the western Himalaya during the last few decades (e.g. Bishop and others, 2004), yet little is known about glacier variations in the Naimona'nyi region. In this work, glacier variations in the Naimona'nyi region have been surveyed using a series of digital images (Landsat MSS in 1976, TM in 1990 and 1999, and ASTER in 2003; Table 1) and 1:50000 topographic maps produced from aerial photographs in 1974 .

\section{METHODOLOGY}

This paper compares the results of two alternative methods for studying glacier variations. The most popular methods of research on glacier variations by remote sensing focus on how to extract glacier information by band algebraic operation, digitization or classification using individual images from different times and then comparing the results

Table 1. Digital satellite images used in the paper

\begin{tabular}{lll}
\hline Sensor & Date & Path/row \\
\hline Landsat MSS & 6 Dec. 1976 & $155 / 39$ \\
Landsat TM & 23 Oct. 1990 & $144 / 39$ \\
Landsat TM & 9 Nov. 1999 & $144 / 39$ \\
ASTER & 3 Oct. 2003 & \\
\hline
\end{tabular}


Table 2. Rmse of verification points in each co-registered image compared with the $1: 50000$ topographic map

\begin{tabular}{lrrrrrr}
\hline & \multicolumn{3}{c}{ Ground-control points } & \multicolumn{4}{c}{ Check points } \\
Year & $\mathrm{X}$ & $\mathrm{Y}$ & Total & $\mathrm{X}$ & $\mathrm{Y}$ & Total \\
& $\mathrm{m}$ & $\mathrm{m}$ & $\mathrm{m}$ & $\mathrm{m}$ & $\mathrm{m}$ & $\mathrm{m}$ \\
& & & & & & \\
\hline 1976 & 17.9 & 12.8 & 22.1 & 35.1 & 25.4 & 43.4 \\
1990 & 9.8 & 5.9 & 11.4 & 10.5 & 10.0 & 14.6 \\
1999 & 6.4 & 6.7 & 9.2 & 12.0 & 8.2 & 14.6 \\
2003 & 2.9 & 2.6 & 3.9 & 7.6 & 7.3 & 10.58 \\
\hline
\end{tabular}

from individual images. In this paper, we report glacier area growth and shrinkage in the Naimona'nyi region during the period 1976-2003 by comparing individual images. The weakness of this method is that it overlooks discrepancies that always exist among sequential images due to different seasons, resolutions and data sources. Thus, this paper develops a new method for studying glacier variations by means of Geographic Information System (GIS) and remotesensing techniques. We integrate all classification results from individual images (1976, 1990, 1999 and 2003) by the algebraic operations in the Arc/Info grid module which enables us to determine mismatched information or unreasonable changes in glacier variations. The results obtained using both the 'individual image' and the 'integrated' method are presented here.

Multitemporal and multi-source digital satellite images have to be accurately orthorectified by a digital elevation model (DEM) before calculating changes based on pixels. Orthorectification eliminates the effects of perspective distortion and reduces the relief displacement on remotely sensed data. For the Naimona'nyi study region, we use the highest-available-resolution DEM data (1:50000 scale, DEM5, cell size $25 \mathrm{~m}$ ). The horizontal accuracy of DEM5 with respect to the $1: 50000$ topographic map of the region is within 1.0 gridcell, i.e. $25 \mathrm{~m}$.

Before orthorectification of the sequential satellite imagery, the height accuracy of the DEM was evaluated by comparing 331 elevation check points on the 1:50000 topographic maps with the corresponding height values for the same locations in the DEM. We obtained an average height difference of $12.37 \mathrm{~m}$, with a standard deviation of $18.52 \mathrm{~m}$. Residual root-mean-square error (rmse) (Hall and others, 2003; Stevens and others, 2004; Kääb, 2005) of the DEM with respect to the topographic map is $+20.93 \mathrm{~m}$.
Table 4. Information table of the integrated grid, 1976-2003, by value of gridcells

\begin{tabular}{lrr}
\hline Gridcell value & Count of gridcells & $\begin{array}{c}\text { Area } \\
\mathrm{km}^{2}\end{array}$ \\
& & \\
\hline 5555 & 714479 & 643.03 \\
5557 & 120 & 0.11 \\
5575 & 1188 & 1.07 \\
5577 & 230 & 0.21 \\
5755 & 1494 & 1.34 \\
5757 & 266 & 0.24 \\
5775 & 824 & 0.74 \\
5777 & 2035 & 1.83 \\
7555 & 4659 & 4.19 \\
7557 & 205 & 0.18 \\
7575 & 1371 & 1.23 \\
7577 & 706 & 0.64 \\
7755 & 2091 & 1.88 \\
7757 & 648 & 0.58 \\
7775 & 3540 & 3.19 \\
7777 & 82141 & 73.93 \\
& & \\
\hline
\end{tabular}

Maximum height deviations were -180.9 and $+27.8 \mathrm{~m}$. The accuracy of orthorectification is within one image pixel. All image data used were converted from disparate sources to a common format defined in Arc/Info grid with Transverse Mercator projection and Krasovsky 1940 spheroid. Coregistration for all orthoimages is based on the 1:50000 topographic map (which is used as the common 'base'), and all the co-registration errors are within one image pixel (Table 2).

Glaciers are mapped by unsupervised classification using band arithmetic, TM4-TM5 for Landsat imagery and TM3NTM4 for ASTER imagery. This is a simple, robust and accurate method for glacier classification because of the very low reflectance of ice and snow in the near and middle infrared (Paul and others, 2002). All results are resampled to the same $30 \mathrm{~m}$ gridcell resolution, and some snow-covered nonglacier areas are removed by filter methods and manual editing. Classification accuracy of individual imagery series since 1976 was analyzed by Kappa technology (Cohen, 1960; Congalton, 1991) using 260 random points. The KHAT accuracy is $91.2 \%$ from the results of the Kappa analysis.

A classification scheme was used in which non-glacier areas were assigned a single-digit value of 5, and glacier areas were assigned a single-digit value of 7 . This classification scheme facilitates the algebraic operations among

Table 3. Remap table of reclassification for reconstructing grid units of glacier variation process

\begin{tabular}{llll}
\hline Grid unit value of the integrated grid & Recode & Area & Category of variation \\
\hline 5557 & 1 & 0.108 & Advanced glacier area, 1999-2003 \\
5577 & 2 & 0.207 & Advanced glacier area, 1990-99 \\
5777 & 3 & 1.832 & Advanced glacier area, 1976-90 \\
7555 & 4 & 4.193 & Retreated glacier area, 1976-90 \\
7755 & 5 & 1.882 & Retreated glacier area, 1990-99 \\
7775 & 6 & 3.186 & Retreated glacier area, 1999-2003 \\
$7777,7757,7577$ & 7 & 75.146 & Glacier area unchanged, 1976-2003 \\
$5555,5575,5755,5757,5775,7557,7575$ & 9 & 647.844 & Non-glacierized area and mismatches
\end{tabular}




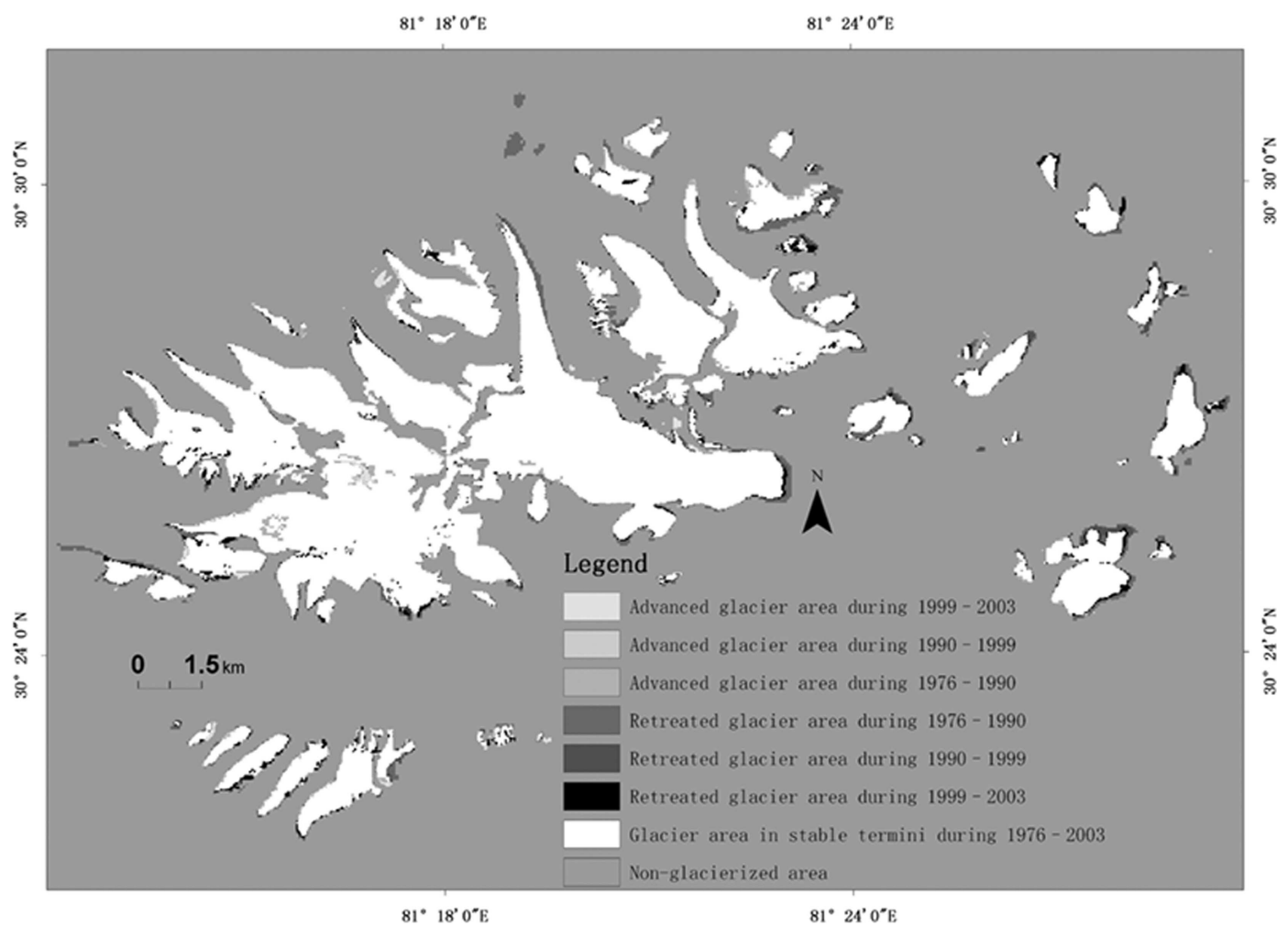

Fig. 1. Glacier area variations in the Naimona'nyi region, 1976-2003.

classification results from images in the Arc/Info grid module. The one-digit value (i.e. 5, 7) from each gridcell was integrated over the four classification results from images (from 1976, 1990, 1999 and 2003) by map algebra to generate a map with a four-digit value in each gridcell that simulates glacier change during the period 1976-2003 (Fig. 1). This enabled us to track glacier variations during the corresponding period both on maps and in tables. Instances in which gridcells indicate changes that occur more rapidly than is considered possible (e.g. 5757, 7575, etc.) are considered mismatches (e.g. 5757 stands for gridcell variation in 'non-glacier area, glacier area, non-glacier area, glacier area' in the 1976, 1990, 1999 and 2003 images, respectively). 'Noise', which is caused by mismatched information or unreasonable changes, such as different data sources or seasonal differences in snow cover in non-glacier areas, is eliminated by reclassification using the remap table (Table 3). All the results are recoded by the Reclass function using remap tables in the Arc/Info grid module. The four-digit integrated value from each gridcell (hereafter called the 'integrated unit') is used to identify advancing glacier areas, where non-glacier areas become glacier areas, and retreating areas, where glacier areas become non-glacier areas during different periods. These regions can be identified by both the integrated map (Fig. 1) and tabulated information (Table 4).

\section{RESULTS}

From the classification results from individual images, the area of glaciers in the Naimona'nyi region was $87.04 \mathrm{~km}^{2}$ in 1976 and decreased to $79.39 \mathrm{~km}^{2}$ in 2003 (Table 5). This shows an obvious decrease in glacier area, and the rate of change varies during different periods. Recession was $2.59 \mathrm{~km}^{2}$ during $1976-90$ (or $0.19 \mathrm{~km}^{2} \mathrm{a}^{-1}$ on average), $0.80 \mathrm{~km}^{2}$ during $1990-99$ (or $0.09 \mathrm{~km}^{2} \mathrm{a}^{-1}$ on average) and
$4.27 \mathrm{~km}^{2}$ during 1999-2003 (or $1.07 \mathrm{~km}^{2} \mathrm{a}^{-1}$ on average). From the individual images the total area decrease between 1976 and 2003 is $7.66 \mathrm{~km}^{2}$ or $8.8 \%$ (Table 5).

By the integrated method that we use in this paper, the glacier area was $84.41 \mathrm{~km}^{2}$ in 1976 and $77.29 \mathrm{~km}^{2}$ in 2003 (Table 6), a change of $7.12 \mathrm{~km}^{2}$ or $8.4 \%$. Accelerated recession of glacier area is clearly shown in Table 6 . There is a recession of $2.37 \mathrm{~km}^{2}$ during $1976-90$ (or $0.17 \mathrm{~km}^{2} \mathrm{a}^{-1}$ on average), $1.67 \mathrm{~km}^{2}$ during $1990-99$ (or $0.19 \mathrm{~km}^{2} \mathrm{a}^{-1}$ on average) and $3.08 \mathrm{~km}^{2}$ during 1999-2003 (or $0.77 \mathrm{~km}^{2} \mathrm{a}^{-1}$ on average) (Fig. 1; Table 6). This indicates that glacier retreat in the western Himalaya is dramatic, and has accelerated in recent years.

Glaciers in the Naimona'nyi region have both advanced and retreated during the period 1976-2003. However, the area of glacier recession is much larger than the area of glacier advance (Table 3), and the advancing area decreases through time, while the retreating area increases.

Most of the area of glacier retreat occurred at the termini of glaciers in the southeast of the region (Fig. 1), while most

Table 5. Glacier area change, 1976-2003, by individual image classification results

\begin{tabular}{ccccc}
\hline Year & $\begin{array}{c}\text { Area } \\
\mathrm{km}^{2}\end{array}$ & $\begin{array}{c}\text { Variation in area } \\
\mathrm{km}^{2}\end{array}$ & $\begin{array}{c}\text { Variation rate } \\
\%\end{array}$ & $\begin{array}{c}\text { Speed } \\
\mathrm{km}^{2} \mathrm{a}^{-1}\end{array}$ \\
\hline 1976 & 87.04 & & & \\
1990 & 84.46 & -2.59 & -2.97 & -0.19 \\
1999 & 83.66 & -0.80 & -0.95 & -0.09 \\
2003 & 79.39 & -4.27 & -5.10 & -1.07 \\
Total & & -7.66 & -8.80 & -0.28 \\
\hline
\end{tabular}


Table 6. Glacier area change, 1976-2003, after integration and reconstruction of basic units by remap table

\begin{tabular}{|c|c|c|c|c|c|}
\hline \multirow[t]{2}{*}{ Year } & Area & $\begin{array}{l}\text { Variation } \\
\text { in area }\end{array}$ & $\begin{array}{l}\text { Variation } \\
\text { rate }\end{array}$ & Speed & \multirow[t]{2}{*}{ Grid cell value } \\
\hline & $\mathrm{km}^{2}$ & $\mathrm{~km}^{2}$ & $\%$ & $\mathrm{~km}^{2} \mathrm{a}^{-1}$ & \\
\hline 1976 & 84.41 & & & & $\begin{array}{l}7777,7757 \\
7577,7555,7755,7775\end{array}$ \\
\hline 1990 & 82.04 & -2.37 & -2.81 & -0.17 & $\begin{array}{l}7777,7757 \\
7577,7755,7775,5777\end{array}$ \\
\hline 1999 & 80.37 & -1.67 & -2.04 & -0.19 & $\begin{array}{l}7777,7757 \\
7577,7775,5577,5777\end{array}$ \\
\hline 2003 & 77.29 & -3.08 & -3.83 & -0.77 & $\begin{array}{l}7777,7757 \\
7577,55557,5577,5777\end{array}$ \\
\hline Total & & -7.12 & -8.44 & -0.26 & \\
\hline
\end{tabular}

of the area of advance occurred at the termini of glaciers in the northwest of the region. Glaciers in the southeast are retreating faster than those in the northwest.

\section{DISCUSSION}

This paper explores an alternative method for studying glacier variations. Comparison of the results of glacier area from individual images (Table 5) with those from the integrated method indicates less variation in glacier area and a more obvious trend of accelerated retreat in the integrated and recoded grid data (Table 6) in the Naimona'nyi region. We could detect discrepancies in glacier extraction among the sequential images both graphically (Fig. 1) and numerically (Table 4). Since most of the 'noise' or mismatches could be detected and eliminated in the temporal spatial integrated map data by reconstruction using remap tables in the Arc/Info grid module, this provides a better quantification of glacier variations. Additionally, the integration method enables us to determine different variation characteristics during different periods over space in the research region. We were able to identify some misclassified areas (e.g. high-elevation rock ridges surrounded by glaciers that were misclassified as advancing glaciers due to snow cover; Fig. 1), something that is hard to determine by classification results from individual images only. These areas could be identified in the integrated map and can be verified in the near future using glaciological information or detailed field surveys.

Our research shows that the recession of glaciers in the Naimona'nyi region is more extensive and faster in recent years than before. The decrease of $8.4 \%$ of the total area during 1976-2003 is larger than the average 7\% retreat of glaciers in high Asia since the 1960s (Yao and others, 2004). Alpine glacier recession is occurring in many places in Asia (e.g. $4.8 \%$ loss of the total area of $889 \mathrm{~km}^{2}$ during 1969 2002 in the Geladandong region (Ye and others, in press; $13.8 \%$ recession in the Ürümqi river drainage area during 1964-92 (Chen and others, 1996); 17\% loss in the A'nyêmaqên mountains of the Yellow River source during 1966-2000 (Yang and others, 2003); and 10.3\% decrease in the western Qilian Shan during 1956-90 (Liu and others, 2002)). The recession of glaciers in the western Himalaya has accelerated, which coincides with glacier variation trends in high Asia (Yao and others, 2004). The retreat is due to the negative glacial mass balance and is affected by rising temperature and decreasing precipitation over the Tibetan Plateau (Yao and others, 2004).

Glacier variations in the Naimona'nyi region during 1976-2003 also show spatial differences. Retreat usually occurred in the southeast, while advance always occurred in the northwest. However, the cause for advance or retreat of some glaciers in the region has not been identified because of the paucity of field-survey and regional meteorological data. Furthermore, this work only studied variations of glacier area. It does not include height variations which might show downwasting. In the future, we will extract and verify DEMs using various ASTER (bands $3 \mathrm{~N}$ and $3 \mathrm{~B}$ ) data sources, and calculate vertical differences from DEM5 to study the volume variation of glaciers in the region. This will enable us to generate a more comprehensive view of glacier variations in the Naimona'nyi region, which will require detailed study in the near future.

\section{CONCLUSIONS}

The integrated unit with a four-digit value over the four images (from 1976, 1990, 1999 and 2003) in the Naimona'nyi region enables us to determine mismatched information or unreasonable changes in glacier variations. By integration of all sequential spatial data through time based on fundamental grid units, most of the mismatches could be detected and eliminated in the integrated data using remap tables in Arc/ Info grid. The comparison of glacier area from 1976 to 2003 (Tables 5 and 6) demonstrates that the integrated method did well in reducing discrepancies from various data sources, different seasons and different resolutions. The integrated method achieved more accurate results in glacier variations by applying the Arc/Info manipulations of the original classification results from individual images. This paper provides an alternative method of synthesized research on glacier variation using multi-source and multitemporal data.

Our results show that areas of both glacier retreat and advance exist in the Naimona'nyi region during the period 1976-2003; however, retreat dominates, and increases through time. Glaciers in the southeast are retreating more than those in the northwest. The $8.4 \%$ decrease of glacier area in the Naimona'nyi region is dramatic compared with other regions and the average glacier recession in high Asia since the 1960s.

\section{ACKNOWLEDGEMENTS}

We thank G. Hamilton and P. Mayewski for assistance with data collection, L. Thompson and E. Mosley-Thompson for helpful comments on the paper, and $\mathrm{H}$. Brecher and K. Jezek for careful reviews that significantly improved the paper. Thanks also to S. Kaspari and B. Grigholm for help with the English. The work is supported by the Special Funds for Major State Basic Research Project (2005CB422004), by the National Natural Science Foundation of China (40401054, 40121101, 40601056), by the 'Talent Project' of the Chinese Academy of Sciences (CAS) and the Project of CAS Knowledge Innovation Program (KZCX3-SW-339).

\section{REFERENCES}

Bindschadler, R., J.A. Dowdeswell, D. Hall and J.G. Winther. 2001. Glaciological applications with Landsat-7 imagery: early assessments. Remote Sens. Environ., 78(1-2), 163-179. 
Bishop, M.P. and 16 others. 2004. Global land ice measurements from space (GLIMS): remote sensing and GIS investigations of the Earth's cryosphere. Geocarto Int., 19(2), 57-84.

Chen, J., C. Liu and M. Jin. 1996. Application of the repeated aerial photogrammetry to monitoring glacier variation in the drainage area of the Ürümqi River. J. Glaciol. Geocryol., 18(4), 331-336. [In Chinese with English summary.]

Cohen, J. 1960. A coefficient of agreement for nominal scales. Educ. Psychol. Meas., 20(1), 37-46.

Congalton, R.G. 1991. A review of assessing the accuracy of classifications of remotely sensed data. Remote Sens. Environ., $37(1), 35-46$.

Dyurgerov, M.B. and M.F. Meier. 2000. Twentieth century climate change: evidence from small glaciers. Proc. Natl. Acad. Sci. USA (PNAS), 97(4), 1406-1411.

Haeberli, W., R. Frauenfelder, M. Hoelzle and M. Maisch. 1999. On rates and acceleration trends of global glacier mass changes. Geogr. Ann., 81A(4), 585-591.

Hall, D.K., K.J. Bayr, W. Schöner, R.A. Bindschadler and J.Y.L. Chien. 2003. Consideration of the errors inherent in mapping historical glacier positions in Austria from ground and space (1893-2001). Remote Sens. Environ., 86(4), 566-577.

Jing, Z., B. Ye, K. Jiao and H. Yang. 2002. Surface movement of the Haxilegen Glacier No. 51 of the Huytun River, Tianshan Mountains. J. Glaciol. Geocryol., 24(5), 563-566. [In Chinese with English summary.]

Kääb, A. 2002. Monitoring high-mountain terrain deformation from repeated air- and spaceborne optical data: examples using digital aerial imagery and ASTER data. ISPRS J. Photogramm. Rem. Sens, 57(1-2), 39-52.

Kääb, A. 2005. Combination of SRTM3 and repeat ASTER data for deriving alpine glacier flow velocities in the Bhutan Himalaya. Remote Sens. Environ., 94(4), 463-474.

Liu, S., Y. Shen, W. Sun and G. Li. 2002. Glacier variation since the maximum of the Little Ice Age in the western Qilian Mountains, northwest China. J. Glaciol. Geocryol., 24(3), 227-233. [In Chinese with English abstract.]

Lu, A., T. Yao, S. Liu, L. Ding and G. Li. 2002. Glacier change in the Geladandong area of the Tibetan Plateau monitored by remote sensing. J. Glaciol. Geocryol., 24(5), 559-562. [In Chinese with English abstract.]

Mayewski, P.A. and P.A. Jeschke. 1979. Himalayan and transHimalayan glacier fluctuations since A.D. 1812. Arct. Alp. Res., 11(3), 267-287.
Meier, M.F. 1973. Evaluation of ERTS imagery for mapping and detection of changes of snowcover on land and on glaciers. In Freden, S.C., E.P. Mercanti and D.E. Witten, eds. Proceedings of Symposium on Significant Results obtained from Earth Resources Technical Satellite-1. Washington, DC, National Aeronautics and Space Administration, 863-875.

Miller, K.J., ed. 1984. The International Karakoram Project: proceedings of the international conference. Cambridge, etc., Cambridge University Press.

Oerlemans, J. 1994. Quantifying global warming from the retreat of glaciers. Science, 264(5156), 243-245.

Paul, F., A. Kääb, M. Maisch, T. Kellenberger and W. Haeberli. 2002. The new remote-sensing-derived Swiss glacier inventory. I. Methods. Ann. Glaciol., 34, 355-361.

$\mathrm{Pu}$, J., T. Yao, N. Wang, L. Ding and Q. Zhang. 2001. Recent variations of the Malan Glacier in Hoh Xil region of the Tibetan Plateau. J. Glaciol. Geocryol., 23(2), 189-192. [In Chinese with English abstract.]

Stevens, N.F., H. Garbeil and P.J. Mouginis-Mark. 2004. NASA EOS Terra ASTER: volcanic topographic mapping and capability. Remote Sens. Environ., 90(3), 405-414.

$\mathrm{Su}, \mathrm{Z}$. and 6 others. 1999. Glacier response to climatic change and its trend forecast in the Qinghai-Tibet Plateau. Adv. Earth Sciences, 14(63), 607-612. [In Chinese with English abstract.]

Wang, Z. and C. Liu. 2001. Geographical characteristics of the distribution of glaciers in China. J. Glaciol. Geocryol., 23(3), 231-237. [In Chinese with English abstract.]

Yang, J., Y. Ding, S. Liu, A. Lu and R. Chen. 2003. Glacier change and its effect on surface runoff in the source regions of the Yangtze and Yellow rivers. J. Natur. Res., 18(5), 595-602. [In Chinese with English abstract.]

Yao, T.D., Y.Q. Wang, S.Y. Liu, J.C. Pu, Y.P. Shen and A.X. Lu. 2004. Recent glacial retreat in High Asia in China and its impact on water resource in Northwest China. Sci. China D, 47(12), 1065-1075.

Ye, Q., S. Kang, F. Chen and J. Wang. In press. Glacier variations on Geladandong mountain, central Tibetan Plateau, from 1969 to 2002 using remote-sensing and GIS technologies. J. Glaciol.

Zheng, D. and L. Zhu, eds. 2003. Formation, environment and development of the Tibetan Plateau. Shijiazhuang, Heibei Science and Technology Press. [In Chinese.] 